\title{
MYTHOLOGICAL FOUNDATIONS OF SOCIETY VIRTUALIZATION
}

\section{Okorokova V. V.}

\section{INTRODUCTION}

Every cultural-historical era is characterized by certain mental attitudes, mental constructions and ideas that form the image of social reality. The latter determines man's place in social space, his attitude to the world around him, and most importantly, his knowledge. It is through cognitive abilities in the human mind the images are formed and they are the basis of the social ideal, social reality, prognostic orientation of comprehension of social existence.

Consciousness as a way of reflecting and understanding reality acts as a way of human existence. To explain various phenomena, both to himself and to others, man seeks to use the most understandable definitions and comparisons. Within the framework of social system, general concepts appear about general and regular causes of events; this, in turn, contributes to the formation of mass consciousness of people. This is an important circumstance, since myth is one of the ways of perceiving reality; it is a form of reflection/construction in the consciousness of reality.

The point is that mythological consciousness has the power to construct from the fragments, chaos of the external world of impressions, an integral picture of the world, determining the style of thinking and the way people exist in this world. In all historical times, human consciousness contained mythological components (images, symbols, beliefs, convictions, prejudices) of all value levels and strata existing in a given culture. This is the basis of any sociocultural phenomenon, the basis of all forms of being, perceived by man as the only possible reality. It can be said that myth is an idealized, valuably and emotionally colored "mark" of reality, the existence of which is vital to the structure of human consciousness ${ }^{1}$.

1 Галанина Е.В. Мифологические миры Постмодерна. Фундаментальные исследования. 2015. № 2-1. URL: http://www.fundamental-research.ru/ru/article/ view? $\mathrm{id}=36644$ 
In other words, being one of the forms of man's conscious activity, myth is a reflection of transformational processes in society, namely, mythological consciousness does not only disappear in historical forms of culture, but plays a significant role in their generation. Specific myths eventually recede into the past, but mythological thinking as a way and a form of spiritual development of the world continues to play one of the main roles in the process of cognition of the surrounding world. Having undergone a significant transformation in different eras, myth changes only the scope of implementation, but not the purpose.

That is, myth and culture act as a single organism, in which myth is the core of culture, a type of functioning of a cultural program that carries in its infancy the possible paths of development of the mythological foundations of culture. This idea allows some scientists to consider the existence of culture as a gradual deployment of the program embedded in the myth, and the extinction - its full implementation $^{2}$. As a result of the researches, myth is considered as a method of forming mass consciousness ${ }^{3}$. Very well this trait of the myth is reflected in the words of E. Cassirer "Myth is always with us and only hides in the darkness, waiting for its time".4.

The main feature that we should pay attention to in our case is that the mythological aspect in the mass consciousness manifests itself especially during periods of crises and growing social conflicts, which is typical for the current situation in society, when there are sharp changes in the consciousness and behavior of people. This is largely due to the intensive introduction of information and communication technologies, as a result of the virtualization of society.

In modern social philosophy, this problem is an actual direction in scientific researches, since it allows to identify ontological and epistemological foundations of the transformation of post-society, which is expressed in the works of A.V. Gulimova, L.G. Ionin,

2 Сидорович Ю.М. Мифологические основания культуры. Наука. Релігія. Суспільство. 2008. № 1. С. 75.

3 Стариков А.Г. Мифотворчество как метод формирования массового сознания. Вестник ДГТУ. 2009. Т 9. № 4 (43). С. 746.

4 Кассирер Э. Технологии современных политических мифов. URL: https://iphras.ru/uplfile/root/biblio/ppy_4/6.pdf 
M.A. Kim, E.G. Kozlova, A.V. Matetskaya, P.K. Ogurchikov, E.V. Pilyugina, A.E. Fursova, A.V. Chernysheva and others.

For example, A.V. Chernysheva says that despite the fact that modern man considers himself a rational being, whose life and activity are very far from myth, at the same time, all our ideas about the world around us, regardless of our desire, are mythological in nature ${ }^{5}$. According to E.V. Pilyugina, postmodern is a period of the widespread distribution of mythologies, the era of mass mystification and pan-mythologization of reality ${ }^{6}$. In turn, L.G. Ionin generally speaks of the "enchantment" of the world, a new magical era that sets in as a result of a growing complication of social and technological problems. In their totality, the noted ideas indicate a necessity to consider the issue of mythologization of thinking in the virtualization of modern society, to identify the specifics of the manifestation of myth in it?

\section{Ontological bases of public consciousness mythologization in modern society}

Despite the availability of various studies in the field of modern myth-making, the problem of determining the role of myth, its function in society does not have a common definition. Among the well-known thinkers of the turn of the $20^{\text {th }}-21^{\text {st }}$ centuries who considered the category of myth in connection with public consciousness, R. Bart, E. Cassirer, A. Losev, M. Eliade should be noted.

It is interesting that M. Eliade, when defining the concept of myth, drew attention to the difficulty of finding such a definition that would be accepted by all scientists and at the same time accessible to non-specialists, continuing with the fact that myth is one of the extremely complex realities of culture, and it can be studied and interpreted in the most numerous and complementary aspects.

5 Чернышева А.В. Мифологизация реальности и реальность мифа в культуре информационного общества. URL: hmbul.ru/articles

6 Пилюгина Е.В. Современная социальная реальность: панмифологизация, информационные войны и кризис Постмодерна. Вестник ВГУ. Серия: Философия. 2014. № 4. С. 84.

7 Ионин Л.Г. Новая магическая эпоха. Логос. 2005. № 2(47). URL: www.ruthenia.ru/logos/number 
Therefore, according to M. Eliade, the following definition is a more acceptable interpretation of myth, since it covers the question that interests us more widely: "Myth presents a sacred story, tells about an event that occurred in memorable times of "the beginning of all beginnings"8. Myth tells how reality, thanks to the exploits of supernatural beings, reached its embodiment and implementation, whether it is a comprehensive reality, the cosmos, or just a fragment of it.

French philosopher R. Barth, when defining a myth, draws attention to the fact that myth is a communicative system, a message, therefore, myth cannot be a thing, a convention or a idea, it is one of the means of meaning, myth is a form ${ }^{9}$. It has the historical boundaries of this form, the conditions for its use, to fill it with a social content. The scientist reveals general features of any mythologized reality. So, according to $\mathrm{R}$. Barth, myth is not the reality, but a symbolic reflection of the reality, but it is a "crooked mirror". "Curvature" is given by history - both a real history of a particular society, and a history of the emergence of a particular myth in the society: "myth is a word chosen by history"10.

"Myth is not a fiction or a figment, it is not a fantastic fiction, but logically, that is, first of all, the dialectically necessary category of consciousness and being in general," by these words A.F. Losev characterizes the category of myth. The thinker gives a summary of the analysis of the characteristics of myth, with all its limitations and divisions: "Myth is a personal being, or rather, a way of being personal, a personal form, and a face of personality. Myth is an intelligently given symbol of life, the necessity of which is dialectically obvious" $"$.

Based on the above examples of determining the category of myth, it follows that the most important function of myth is the creation of a model, an example, a sample. Myth is a generalized comprehension of reality, in which a representation coincides with reality itself, and a mythological comprehension of something does

8 Элиаде М. Аспекты мифа. М.: «ACADEMIA», 1995. С. 15.

${ }^{9}$ Барт Р. Мифологии. М.: Издательство М. и С. Сабашниковых, 2004. С. 72.

${ }^{10}$ Ibid.

11 Лосев А.Ф. Диалектика мифа. М: Мысль, 2001. URL: http://yanko.lib.ru/ books/philosoph/losev-dialektika_mifa-a.htm 
not require any evidence or substantiation by facts, on the contrary, it itself "from above" gives an explanation of the essence and causes of various phenomena ${ }^{12}$.

One of the essential facets of myth-making is precisely the fact that man who lives "inside" of mythological consciousness does not distinguish mythical plots from reality, puts them in the forms of reality itself. As a form of practical-spiritual mastering of reality, the specificity of which is manifested in the transcoding by the consciousness of facts of reality, myth models the events and phenomena of reality, depicting them in a different plane than reality. Myth is characterized by such features as universality, certainty, integrity and unity of all elements, accessibility, and simplicity. Having such characteristics, myth from a real, contradictory, complex, ambiguous world creates a new world that is distinctive from the real one.

Between myth and mass consciousness there are relationships of interdependence. Myth is supported by the mass consciousness; mass consciousness is based on myth. Mythological consciousness as a way of reflecting reality and myth as a means of storing and transmitting information arise simultaneously with mass consciousness. The common property of mythological consciousness and mass consciousness can be called their manifestation at all levels and in all forms of social consciousness. The difference is that myth consciousness reflects reality, revealing the level and the method of its development, determining the substantial (qualitative) aspect of this process, and mass consciousness reveals the extent of the spread of specific myths in public consciousness, being at the same time a way of functioning of myth creation.

Mass consciousness is a favorable environment for the spread of myths due to an uncritical attitude to reality, the need for a miracle, the inertia of thinking, the credibility of the source of information, and the simplified perception of reality.

For the existence of mass consciousness, stable ideas about the world, based on tradition, as well as a guiding and unifying idea, focus on the future, are necessary. The relationship between myth and mass

12 Ситник О.В. Політична міфологія: проблема визначення. Науковий вісник Східноєвропейського національного університету імені Лесі Українки. 2013. № 27. С. 108-109. 
consciousness can be schematically represented as follows: collective unconscious - archetypes, emotional-sensual sphere - stereotypes; meaning-creating sphere - axiotypes. In their pure form, these phenomena do not exist, but, based on the structure of mass consciousness (the internal mechanism of its formation), we can conditionally distinguish the named types corresponding to them at each level of the revealed structure ${ }^{13}$.

At the beginning of the study, it should be noted that comparing modern social mythology and primitive mythology, S.S. Vasiliev notes that in both cases we are faced with an irrational regulator of behavior that adapts an individual to the community. The departure to other worlds, felt as really existing, gives man the illusion of belonging to the real world, the illusion of the possibility of realizing his aspirations, the embodiment of ideals. Beliefs in ideals, desire for their implementation relate mythology with religion. In its extreme manifestations, modern mythology includes actions (worship, rites, rituals) and moods corresponding to them ${ }^{14}$.

The noted thought allows us to state that the power of mythological thinking is reaffirmed in all spheres of human life. It would seem that mythology is an archaic form of consciousness, which should be supplanted by scientific achievements and can no longer claim a dominant role in the worldview of modern man. But now, in the globalized and integrated world, myth needs to be understood a little more broadly than as figurative representations of ancient civilizations.

Based on these provisions E.V. Pilyugina affirmatively draws attention to the total mythologization of what happens ${ }^{15}$. So, according to her thought, myths of the postmodern society program social life, filling it with certain meanings, providing the essence of social as such. The pan-mythologization of reality without fail involves the observance of two important conditions: the singularity

13 Васильев С.С. Механизмы и уровни внедрения мифа в массовое сознание: масс-медиа как инструмент социального мифотворчества. Историческая и социиально-образовательная мысль. № 2. 2009. С. 39.

${ }^{14}$ Ibid., p. 41.

15 Пилюгина Е.В. Феномен панмифологизации действительности и актуальные мифологемы. Современные исследования соииальных проблем (электронный научный журнал). 2015. № 1. URL: https://cyberleninka.ru/article/ fenomen-panmifologizatsii-deystvite. 
of being and the transparency of consciousness. By singularity is meant the content of diverse significations, signs and meanings of various cultural (in the form of attractors and narratives) and social (in the form of events) phenomena that provide a modality of life and appear in the form of a particular social subject or a segment of social life. The most striking practical implementation of the singular world is the Internet space. Singularities are individual consumers and creators, as well as "sites" and "blogs", social networks are all participants, techniques, and technologies of cyberspace. Social mythologemes play the role of key programs, "browsers" of the socially-informative sphere.

The second condition for the pan-mythologization of reality, according to E.V. Pilyugina - the transparency of consciousness, which is ensured by the fundamental freedom of communication and information, which removes any restrictions and as a result invalidates the value perception of reality ${ }^{16}$. Under the conditions of a singular being, which is dynamic and unpredictable, transparent, "nullified", "devalued" consciousness is not in itself capable of determining life horizons. Man appears to be in a state of weightlessness: it is impossible to understand where the "top" is, where the "bottom" is.

Continuing the study of modern mythological thinking, the researcher argues that modern social reality, "purified" from any restrictions consciousness creates the conditions for widespread mystification and simulation of reality using the most effective tool today - mythologemes. In modern society, proliferation occurs every second and everywhere - the aggressive growth of individual ideas, their appropriation of an axiomatic status, and then, through these ideas, the total programming of social behavior. It is hardly possible to resist this process today; it is so universal, uncontrollable, and immanent to the present, i.e. postmodern society.

The above ideas of E.V. Pilyugina regarding the panmythologization of reality just very well reflects the main feature of modern mythological thinking is that the information revolution has also led to the transformation that mythological consciousness is undergoing, since the myth of the $20^{\text {th }}$ century intends to return to man

${ }^{16}$ Ibid. 
a sense of emotional and intellectual comfort and solace in the midst of chaos, thereby taking on one of the main functions of religion - the solace function. The task of myth of the $20^{\text {th }}$ century is not overcoming the universal chaos by the human mind, but an endless immersion in this chaos ${ }^{17}$.

Based on these considerations, E.G. Kozlova comes to the conclusion that modern society is in search of a new myth, explaining this by the fact that in such a chaos of information, the creation of positive reality that explains all the events, their legitimate and nonrandom nature, has become a necessary need for society ${ }^{18}$. Considering myth as a form of collective thinking, we can see that the modern world still retains traces of mythical behavior: for example, the acceptance of some symbols by the whole society is interpreted as the preservation of collective thinking. The only significant difference is that most individuals who constitute modern society have personal thinking that missed, or almost missed, among members of traditional societies.

Of particular interest in this sense there are the ideas of E.V. Galanina, who draws attention to the fact that modern culture expresses its own "mythos"19.

And in this sense, postmodernism establishes its own order in the perception of the world as an unstable semantic environment, suggests its own system of value guidelines: pluralism, polyphonism, tolerance, alternativeness, variability, equivalence, and openness as the leading principles of the existence of culture. It will take time before the modern man opens up the whole mythologized cosmos of postmodernism.

The vitality of myth is also explained by the desire to explain the incomprehensible phenomena of the surrounding reality, to obtain a consistent picture of the world or to escape from real

17 Автономова Н.С. Миф: хаос и логос. Заблуждающийся разум?: Многообразие вненаучного знания. - M. : Политиздат, 1990. URL: https://www.twirpx.com/.../Мифология/Научные статьи и сборники

18 Козлова Е.Г. Медиатизация культуры и мифы современности. Современные исследования соџиальных проблем (электронный научный журнал). № 8 (52). 2015. С. 431.

19 Галанина Е.В. Мифологические миры Постмодерна. Фундаментальные исследования. 2015. № 2-1. URL: http://www.fundamental-research.ru/ru/article/ view?id=36644 
problems. Myth as a narration that replaces reality, it is an objectification of mythological consciousness, acting as a primary rationalization of the initially irrational. Since mythological consciousness is directed to the domain of the unknown, the explanatory scheme (myth) narrows this sphere, leaving an irrationalized remainder, which stems from the limited understanding of this subject and the ability of the mind to explain the inexplicable, so imagination comes to the rescue $\mathrm{e}^{20}$.

\section{Myth and the Internet: specificity of the relationship}

Modern society is characterized by modern researchers as being virtualized. New images of virtual reality simulate social reality, inviting people to participate in the construction of "another world". Anyone who successfully manipulates images or is simply involved in this process always acquires a relatively high social status and, in his own practices, follows the imperative of virtualization of society. The one whose reflection is focused on the idea of the reality of society is more likely to be in the lower layers of the stratification pyramid.

Therefore, the word "virtual" itself expresses the will of man, and society as a whole, to further transform social relations. According to D.V. Ivanov metaphor of virtuality perfectly captures, that is, combines in one model new sociocultural phenomen: postmodernism, computerization, and the development of the Internet ${ }^{21}$. The power of a new analytical metaphor is revealed when a "gap" between the socially real and the socially virtual is revealed.

Studying the influence of information technology on mythological consciousness, A.N. Gulimova comes to the conclusion that the manipulative "genius" of the modern way of forming a mythological picture of the world lies in the fact that man does not see the artificiality of the created information messages ${ }^{22}$.

20 Васильев С.С. Механизмы и уровни внедрения мифа в массовое сознание: масс-медиа как инструмент социального мифотворчества. Историческая и сощиально-образоваптельная мыслль. № 2. 2009. С. 37.

Иванов Д.В. Виртуализация общества. СПб: «Петербургское Востоковедение», 2000. URL: http://lib.ru/POLITOLOG/ivanov_d_v.txt

22 Гулимова А.Н. Экранная культура как форма существования современной. Знание. Понимание. Умение. 2011. № 1. С. 252. 
The information provided today by the mass media, the Internet, suggests that the content of the main ideological myth in modern society is neoliberalism, the mythology of which consists of such components as democratic values, market relations, and the rule of law.

The Internet allows itself to create a virtual image that "embellishes" its real or compensative shortcomings, presents it in a desirable form, and also embodies the innermost dreams and desires that could not be realized in real life. Virtual reality provides man with the opportunity to realize those qualities that remain in the shadow in the real world of social relations; we can say that virtual reality in our time is a way of self-expression of the $20^{\text {th }}$ century man.

Thus, in virtual space, we deal not only with the reflection of the external side of real systems, but also with the reflection of possible and even impossible, with the world of human hopes and illusions.

Thus, virtualization in general, and the Internet in particular, provide a huge number of people with unprecedented opportunities in the history of self-realization of the "Self-concept" modification, moreover, as "I-for-myself" and "I-for-others". A proof of this is the already widespread network of online stores, computer games, etc. It is enough to draw attention in this regard to active discussions about the virtual person as an image of a new person, the main area of life is the virtual space.

The ideas noted above allow some scientists who study the problem of virtualization of society to talk about the emergence of a special form of individual and collective consciousness and selfconsciousness - "virtual consciousness and self-consciousness." One of the distinguishing features of this consciousness is its nonlocality ${ }^{23}$.

In this case, studying the connection between myth and the Internet, M.A. Kim claims that it is mythology that can create images or fill new mythological models with new content to manipulate public consciousness ${ }^{24}$. In turn, mythological thinking sets the tone for

23 Луценко Е.В. Виртуализация общества и повышение качества его базиса. URL: http://lc.kubagro.ru/artickles/127/127.htm

24 Ким М.А. Мифологическое мышление в условиях символического потребления. Известия Саратовского ун-та. 2013. Т. 13. Сер. Философия. 
consumption as one of the spheres of social relations, so the formation of symbolic consumption directly depends on the transmission of certain myths through the media.

Thus, the media, television and film culture, computer technologies create a favorable environment for the functioning of myths in mass consciousness. The flow of information through various media channels to a greater extent than with interpersonal communication is the subject to the norms of communication accepted in the society. Significant cultural values play the role of certain information signals distributed in society in a landmark, symbolic, and also figurative form ${ }^{25}$.

However, when studying the modification of myth in the context of virtualization of society, one should take into account the fact that modern myth is significantly different from traditional. It does not occupy a total place in the culture, but it is dispersedly introduced into it, sometimes not obvious. This is due to the fact that the possibility of transformation is inherent in the very nature of myth; moreover, we can talk about both a synchronous and diachronic section of this process. According to some scholars, this is due to the fact that modern screen culture appears as a mythological culture at its core, and myth is insensitive to rational arguments, it cannot be denied with the help of evidence; myth has the quality of integrity, linking, within the framework of a single reality, opposite and mutually exclusive pictures of the world ${ }^{26}$. These qualities of myth and mythological systems allow them to remain the leading way of structuring the world in critical periods, not only during natural and social disasters, as well as ideological crises, but also in moments of individual psychological upheaval.

The magic of the screen gives rise to a new mythology, with the help of which the approval of models of human behavior in culture, the placement of individual being in a new system of social and cultural coordinates takes place. Screen culture gives rise to myths in

Психология. Педагогика. Вып. 1. URL: https://cyberleninka.ru/article/mifologi cheskoe-myshlenie-v-usloviyah-s...

25 Васильев С.С. Механизмы и уровни внедрения мифа в массовое сознание: масс-медиа как инструмент социального мифотворчества. Историческая и соииально-образоваптельная мысль. № 2. 2009. С. 44.

26 Ольховиков К.М. Актуальность культурного мифа. Вестник ЮУрГУ. № 9. 2009. URL: archive.vestnik.susu.ru/pdf 
the broad and narrow sense of the word; it not only distorts reality for the sake of one or another social and cultural demand, but also gives rise to myths of social ownership, distorting the self-concept of the mass audience ${ }^{27}$.

For viewers who are accustomed to the constant consumption of screen products, the psyche works in a mode of not meaningful perception, but an impulsive response. This mode of operation of the psyche contributes to unregulated behavior, makes man be vulnerable to any impact. Constant overload of perception leads to clip manipulation of semantic units. The value collage of perception resulting from the habit of constant consumption of screen products becomes the basis for mythologization of consciousness of the modern man. It is known that reading develops abstract thinking, trains attention concentration and the ability to build a three-dimensional, figurative idea of the object. "Man who doesn't read" loses the ease of association, the emotional subtlety of perception, and the ability to be creative. Subsequently, he begins to perceive the virtual version of television production as a reality of the surrounding reality and does not notice how the deep feelings are replaced by superficial, emotional reactions.

All this begets the perception of reality not as wholeness, but as a set of fragments, which entails the disintegration of the integral picture of the world and the disintegration of the inner world of man into several parallel worlds, in one of which he lives, in the other he works, in the third he works, in the fourth he rests, in the fifth he loves, etc. The "decaying" consciousness of man feels the need to flee from reality - this is "withdrawal" into computer games, drug or alcohol addiction, etc ${ }^{28}$.

The aforementioned allows us to say that modern information culture, on the one hand, is becoming one of the manifestations of past-oriented mythology, but on the other, it is creating its own new mythology.

The task of new myths generated by the screen is the liberation from fears of unknown and uncontrolled processes taking place in

27 Огурчиков П.К. Экранная культура как новая мифология. 2009. URL: https://cyberleninka.ru/article/ekrannaya-kultura-kak-novaya-mifologiya

28 Гулимова А.Н. Экранная культура как форма существования современной. Знание. Понимание. Умение. 2011. № 1. С. 254. 
modern culture. On-screen culture offers the viewer a new mythological reality in which acceptable images and boundaries of the future can be constructed, frees from fear of tomorrow, offers an imaginary "paradise" of illusions, behind which more advanced technologies of submission and control over the "silent majority" are hidden, imposing on them convenient for society priorities ${ }^{29}$.

Exploring the influence of screen culture on mythological consciousness, P.K. Ogurchikov says that modern computer technology has helped the fantasy world acquire the reality of an $\operatorname{artifact}^{30}$. If prior to the total introduction of information technologies, the previously existing cinematic models, in one way or another, falsified reality (the director took certain "imprints of reality" and mounted them in accordance with his conception, the viewer believed in this story because of its photographic nature), then modern screen culture began to turn into the world of images in which man does not experience true reality, being protected from it by myth. Modern screen culture is a collection of images that are created and exist according to the laws of myth construction. Cinema, like myth, doesn't refer to the mind, but it perceives with one's heart, causing desires and appealing to the senses. Like myth, it focuses on imitation of reference patterns, manipulating values and creating the illusion of reality. Finally, cinema, based on the laws of myth construction, creates the dominant role of the author over the subject or object of the image on the screen.

In this case, S.E. Salnikov's ideas deserve special attention, who studies myths in cyberspace, claims that speaking of the modern "postindustrial" formation in the context of virtual reality models, it seems logical to talk not about the transcendental, but the technological inspiredness of myth as a form of quasi-reality that determines the future consciousness of the "information society" 31 .

29 Козлова Е.Г. Медиатизация культуры и мифы современности. Современные исследования сочиальных проблем (электронный научный журнал). № 8 (52). 2015. C. 432.

30 Огурчиков П.К. Экранная культура как новая мифология. Аналитика культурологии. 2009. URL: https://cyberleninka.ru/article/ekrannaya-kultura-kaknovaya-mifologiya

Сальников С.Е. Мифология киберпространства. Вестник КГУ им. Н.А. Некрасова. 2007. № 1. URL: cyberleninka.ru/article/mifologiyakiberprostranstva 
In fact, the thinker continues, if virtual reality is essentially quasireality that carries a purely information load and is only an emulation of traditional reality, then, being transferred to the outside and technologically modeled, it can very well be considered as a cybernetic "mythological apperception". The question of the immanence of myth of reality does not need to be clarified, while myth that has developed in virtual reality does not seem to be a "myth" in its originally and generally accepted meaning.

If in traditional reality myths are created spontaneously, as a product of the collective unconscious, unable to explain this or that phenomenon from speculative positions (the cognitive basis of myth as a priori source for further abstract knowledge has always had the character of an axiom, an intuitive "revelation" of the abovecategorical property that is not a subject to rational research), in virtual reality and cyberspace, in particular, myth is not an autonomous creation that has, as in reality, irrational roots, but it is presented primarily as an "emulation" of the traditional myth, its transfer to the artificial environment solely to systematize contradictory cultural phenomena, generalize them under the denominator of the phenomenon of "myth" and give the character of "structure" to the virtual cultural space/information field.

It is safe to say that virtual reality myth is informationally and completely coherent with myth of traditional reality, while noting that in the latter myth certainly develops around the image, in most cases of the real. However, it is precisely in this way that such emulation does not verify myth with its source in reality, but instead gives myth the character of subjunctiveness, making conceptually from myth a virtual emulation of myth, quasi-myth or "myth of the myth" as if emphasizing its dualism, pseudo-reality.

This state of affairs is also relevant for public consciousness of virtual communities of the network society, where virtual actors are active consumers and creators of various kinds of myths. Virtual myths are some symbols of faith to which a certain virtual community gives the status of truth. The world of virtual myth is the world of a large virtual community (a network cluster) in which the translation and preservation of this myth takes place. In addition, in any virtual community in a network cluster, each virtual subject, based on its intellectual abilities, tries to model its own virtual myths. However, 
due to the identity of cultural dispositions, myths of representatives of homogeneous virtual communities, as a rule, are distinguished by homogeneity, representing a constantly updated set of mutually affecting, overlapping, complementary artifacts within the boundaries defined by dispositions of the mythological matrix.

In virtual communities, myth-making takes place for a variety of reasons. One of such objective reasons is the preservation in the depths of human consciousness of elements of community (tribal) relations, since for all the successes of man on the civilizational path of development and for any triumph of rational constructions, it is very difficult for him to forget that he has children, parents, brothers, sisters, friends etc.

Therefore, even the most progressive, upward development of human society towards global life cannot completely destroy the roots of myth-making. From this it can be assumed that in the creation of myths, as a new social virtuality, in virtual communities, both mythological and rational structures of social consciousness take part in the inextricable unity.

Such interconnection, interweaving and mutual complementation, according to V.O. Sayapin, can be compared with the principle of "melange thread", where each layer of social virtuality is "present" all the time in the obvious, then in the hidden form ${ }^{32}$. Consequently, virtual myths are complex conglomerates in which mythological procedures interact with rational strategies for their adaptation to social virtuality.

Thus, all spheres of social activity of network society in our time are constantly expanding and more and more globalizing, and consumption is becoming a social practice linking the planetary population. Under these conditions, in the era of accelerated development of virtual communities, many new opportunities for creating and disseminating myths appear, they become virtual more and more and clearly manifest themselves as a new virtual mythology in the socio-political sphere, in online advertising, branding, and other forms of mass culture.

32 Саяпин В.О. Интерсубъективность общественного сознания в сетевом обществе. Вестник Тамбовского университета. Серия Общественные науки. 2016. Т. 2. Вып. 3(7). URL: https://cyberleninka.ru/article/intersubektivnostobschestvennogo-sozna. 
The mythological aspect in the intersubjective public consciousness of the network society today is formed in conditions of accessibility and substantial excess of information about social processes taking place in the virtual communities of this society, which, undoubtedly, affects a form, content, and methods of mass broadcasting of mythological semantic settings. In this regard, virtual myth is comprehended by us as a means of power in politics, as a way of manipulating the public consciousness of virtual subjects in various forms of social virtuality. In general, the concept of virtual myth is contrasted with the concept of true reality and truth.

In modern society, one of the most striking examples of the manifestation of myth is fantasy. So, V.O. Pigulevsky in his book "Irony and Fiction: From Romanticism to Postmodernism" notes that the pillar of fantasy is a distorted epic, myths, legends, traditions, fairy tales $^{33}$. They unite in the fantasy genre not by the principle of their random piling, but based on the need for a wonderful world order of perfect quality: amazing worlds, essential names, legendary heroes, magic objects. In a word, personal and original ideas synthesizing myths based on personal hope, dreams. This is a dream come true through myth and a fairy tale, a multidimensional reflection that forms the space of the miraculous.

Reproducing numerous fantastic ideas, cultural symbols and archetypes, it not only acts as an indicator, reflecting the features and the overall picture of modern culture, but purposefully affects the development of society. As a cultural phenomenon, fantasy promotes fantastic ideals, norms (magic as a real force, the dichotomy of good and evil) into the mass consciousness of the consumer, brings an "attractive promise", and also broadcasts special worldview content through distributed symbols and signs.

In this case, fantasy is a great opportunity to show the world of a wonderful, beautiful existence, where everything is possible. Here illusion becomes real and vice versa: reality can become illusory in the wonderful world. The miraculous world is created, lurking in itself a lot of adventures, mysteries, and extravagant heroes. Accordingly, fantasy is most precisely about utopia in the form of

${ }^{33}$ Пигулевский В.О. Ирония и вымысел: от романтизма к постмодернизму. Ростов-на-Дону: Изд-во «Фолиант», 2002. 418 с. 
science fiction, adventure or detective genre. Dreams about the place of fulfillment of hopes, i.e. utopia, exist together or separately in the fantasy genre.

\section{CONCLUSIONS}

The virtualization of society in modern society acts as a catalyst for deep transformational processes that affect the field of consciousness. And here it should be noted that the virtualization of consciousness strengthens precisely the part of it that generates various images, often of a projective nature, which in essence become the basis of the social ideal, in their entirety, the basis of social reality.

This is the reason not only for the survivability of myth in public life, but its rise in conditions of active improvement of information technologies. In this case, myth appears as an element of projective formations in public consciousness, exists in a variety of manifestations and at the same time contains, as the most common identifying signs, the main feature of the statement is not just a model of the desired, but an image of a new social reality.

\section{SUMMARY}

Thus, the study shows that the relationship of modern myth and iconic culture today seems quite accurate, which makes it possible to assert that mythological thinking is expressed not only as a relic of the past, but also as a constructive component of the cognitive process, laying ethical guidelines and moral values.

One cannot but note the fact that a two-way process is taking place in modern society - on the one hand, computer technologies contribute to the transformation in the field of expression of mythological thinking, on the other hand, the formation of the information society, the emergence of virtual reality are dictated by the need to implement those mythological plots about other worlds that have been popular since antiquity.

The revival of myth today is largely due to the unsatisfactory human need for holistic knowledge of the world. Mythological images affect the social creativity of man, the desire to change the surrounding space. In fact, virtual reality also performs this function it compensates for missing human capabilities that remain unrealized 
in everyday reality. A new mythological reality, which is perceived by man as an alternative to social reality, is created.

\section{REFERENCES}

1. Автономова Н.С. Миф: хаос и логос. Заблуждающийся разум?: Многообразие вненаучного знания. - М.: Политиздат, 1990. URL: https://www.twirpx.com/.../Мифология/Научные статьи и сборники.

2. Барт Р. Мифологии. М.: Издательство М. и С. Сабашниковых, 2004. С. 72.

3. Васильев С.С. Механизмы и уровни внедрения мифа в массовое сознание: масс-медиа как инструмент социального мифотворчества. Историческая и сочииально-образоваптельная мыслль. № 2. 2009. С. 37-47.

4. Галанина Е.В. Мифологические миры Постмодерна. Фундаментальные исследования. 2015. № 2-1. С. 200-203. URL: http://www.fundamental-research.ru/ru/article/view?id=36644

5. Гулимова А.Н. Экранная культура как форма существования современной. Знание. Понимание. Умение. 2011. № 1. С. 252-256.

6. Иванов Д.В. Виртуализация общества. СПб.: «Петербургское Востоковедение», 2000. URL: http://lib.ru/ politolog/ivanov_d_v.txt

7. Ионин Л.Г. Новая магическая эпоха. Логос. 2005. № 2 (47). URL: www.ruthenia.ru/logos/number

8. Кассирер Э. Технологии современных политических мифов. URL: https://iphras.ru/uplfile/root/biblio/ppy_4/6.pdf

9. Ким М.А. Мифологическое мышление в условиях символического потребления. Известия Саратовского ун-та. 2013. Т. 13. Сер. Философия. Психология. Педагогика. Вып. 1. C. 33-36. URL: https://cyberleninka.ru/article/mifologicheskoe-mysh lenie-v-usloviyah-s...

10.Козлова Е.Г. Медиатизация культуры и мифы современности. Современные исследования сочиильных проблем (электронный научный журнал). № 8 (52). 2015. С. 428-438.

11. Лосев А.Ф. Диалектика мифа. М: Мысль, 2001. URL: http://yanko.lib.ru/books/philosoph/losev-dialektika_mifa-a.htm 
12.Луценко Е.В. Виртуализация общества и повышение качества его базиса. http://lc.kubagro.ru/artickles/127/127.htm

13. Матецкая А.В. Процесс индивидуализации и мифологическое мышление в эпоху современности. Ростов-наДону: ПИ ЮФУ, 2007. 257 с.

14. Огурчиков П.К. Экранная культура как новая мифология. Аналитика культурологии. 2009. URL: https://cyberleninka.ru/ article/ekrannaya-kultura-kak-novaya-mifologiya

15.Ольховиков К.М. Актуальность культурного мифа / К.М. Ольховиков, С.М. Ольховикова. Вестник ЮУрГУ. № 9. 2009. C. 131-135. URL: archive.vestnik.susu.ru/pdf

16.Пигулевский В.О. Ирония и вымысел: от романтизма к постмодернизму. Ростов-на-Дону: Изд-во «Фолиант», 2002. 418 с.

17.Пилюгина Е.В. Феномен панмифологизации действительности и актуальные мифологемы. Современные исследования социальных проблем (электронный научный журнал). 2015. № 1. С. 291-307.

18.Сальников С.Е. Мифология киберпространства. Вестник КГУ им. Н.А. Некрасова. 2007. № 1. URL: cyberleninka.ru/ article/mifologiya-kiberprostranstva

19. Саяпин В.О. Интерсубъективность общественного сознания в сетевом обществе. Вестник Тамбовского университета. Серия Общественные науки. 2016. Т. 2. Вып. 3 (7). С. 36-41. URL: https://cyberleninka.ru/article/intersubektivnost-obschestvennogosozna..

20.Сидорович Ю.М. Мифологические основания культуры. Наука. Релігія. Суспільство. 2008. № 1. С. 75.

21.Ситник О.В. Політична міфологія: проблема визначення. Науковий вісник Східноєвропейського наиіонального університету імені Лесі Украӥнки. 2013. № 27. С. 106-110.

22.Стариков А.Г. Мифотворчество как метод формирования массового сознания. Вестник ДГТУ. 2009. Т9. № 4 (43). С. 746757.

23. Фурсова А.Е. Миф и рациональность в динамике культуры. Вестник ТвГУ. Серия «Философия». 2012. Вып. 1-2. C. $124-133$. 
24. Чернышева А.В. Мифологизация реальности и реальность мифа в культуре информационного общества. URL: hmbul.ru/ articles

25.Элиаде М. Аспекты мифа. М.: ACADEMIA, 1995. 240 с.

\section{Information about the author: Okorokova V. V., \\ $\mathrm{PhD}$, Associate Professor,}

Chair of the World History and Methodology of Science,

South Ukrainian National Pedagogical University named after K. D. Ushynsky 26, Staroportofrankivska str., Odesa, 65020, Ukraine 